Annals of Warsaw University of Life Sciences - SGGW

Land Reclamation No 44 (1), 2012: 3-14

(Ann. Warsaw Univ. of Life Sci. - SGGW, Land Reclam. 44 (1), 2012)

\title{
Mapping of Spatial Distribution of Soil Salinity and Alkalinity in a Semi-arid Region
}

\author{
ALI KESHAVARZI, FEREYDOON SARMADIAN \\ Department of Soil Science Engineering, University of Tehran
}

\begin{abstract}
Mapping of Spatial Distribution of Soil Salinity and Alkalinity in a Semi-arid Region. Spatial variability of salinity and alkalinity is important for site-specific management since they are the most important factors influencing soil quality and agricultural production. Geostatistical methods provide a means to study the heterogeneous nature of spatial distributions of soil salinity and alkalinity. The present study was carried out to evaluate the accuracy of different spatial interpolation methods including kriging, cokriging and IDW methods for prediction of spatial distribution of salinity (EC) and sodium adsorption ratio (SAR) in soils of Ziaran region in Qazvin province, Iran. The tracking of the soil profiles was done using a Garmin eTrex-H model global positioning system (GPS) receiver. Sampling was done with stratified random method and sixty soil samples from 0 to $15 \mathrm{~cm}$ depth were collected. After data normalization, the variograms were developed. For selecting the best model for competing on experimental variograms, the lower RSS value was used. Experimental variograms were fitted to spherical and exponential models. The best model for interpretative was selected by means of cross validation and error evaluation methods, such as RMSE method. The sum of $\mathrm{Ca}^{2+}+\mathrm{Mg}^{2+}$ and $\mathrm{Na}^{+}$concentration which were highly correlated with soil salinity and sodium adsorption ratio, respectively, are used as auxiliary parameters in this study. The results showed that kriging and cokriging methods were better than IDW method for prediction of EC and SAR. Finally, the soil EC and SAR maps were prepared, using different spatial interpolation methods in GIS environment.
\end{abstract}

Key words: EC, SAR, kriging, cokriging, IDW, cross-validation.

\section{INTRODUCTION}

Precision agriculture practices in arid and semi-arid areas require periodic information on soil salinity and alkalinity. Salinity and alkalinity are the two of the most important problems on agricultural production in arid and semi-arid regions and are threatening for sustainable agricultural management (Ceuppens et al. 1997; Boivin et al. 2002; Kilic and Kilic 2007). The amount of agricultural lands having salinity and alkalinity problems increase continuously as related to climate, topography, groundwater level and quality of irrigation water (Postel 1989; Ayers and Westcot 1989; Kilic and Kilic 2007). The most common reasons of salinity and alkalinity are low precipitation, high evapotranspiration, and low quality of irrigation water. Saline soils contain soluble salts in sufficient quantities to interfere the growth of most crop plants but they do not contain enough exchangeable sodium to alter soil characteristics (Kilic and Kilic 2007). However, alkali soils include exchangeable sodium in a sufficient quantity to interfere the growth of most crops (Bohn et al. 1985). Soluble salts affect the productivity of soils in two principal ways: changing the osmotic potential of soil solution and 
increasing the content of exchangeable sodium, which produces in most soils an unfavorable physical condition (Pozdnyakova and Zhang 1999). The attempts are made to remediate high saline areas by biological methods and by site-specific irrigation (Mankin et al. 1997). Excess salinity of soil solution can be corrected by leaching with water of good quality. The removal of excess exchangeable sodium requires an application of gypsum amendment. Therefore, development and maintenance of reclamation and irrigation projects on saline soils require accurate and updated information about spatial distributions of soil soluble salts, especially the exchangeable sodium (Pozdnyakova and Zhang 1999). There is a close relationship between soil properties and salinity and alkalinity (Kachanoski et al. 1988; Kilic and Kilic 2007) which is related to soil texture, water content and bulk density (Pozdnyakova and Zhang 1999). When clay content is low, EC is affected by volumetric water content, and EC increased with increasing water content (Kachanoski et al. 1988; Kilic and Kilic 2007). There was a significant relationship between EC and the depth of claypan in the soil profile, and $\mathrm{EC}$ was determined to increase with increasing the depth of claypan (Doolittle et al. 1994; Sudduth et al. 1999). The claypan formed in the agricultural lands complicates water movement through soil profile due to low pore size (Rhoades et al. 1992).

Optimizing spatial sampling scheme to reduce sampling density and estimation of unsampling values can save time and costs (Ferreyra et al. 2002; Li et al. 2007). However, its effectiveness relies on the accuracy of the spatial interpola- tion used to define the spatial variability. Multivariate techniques such as geostatistics have been widely used as estimation tools. Geostatistics provides descriptive tools such as kriging to directly implements the prediction of an attribute at an unsampled location according to known data points within a local neighborhood surrounding (Emery and Ortiz 2007). Many comparisons of various interpolation techniques have been made in respect to different data sets used, different mathematical procedures and different input parameters (Boken et al. 2004; Robinson and Metternicht 2006). The structure of variability in soil properties showed differences according to sampling spacing, soil properties, and method used in the study (Kilic and Kilic 2007). Mohammadi (2000) estimated soil salinity, saturation moisture content, sodium adsorption ratio and the percentage of $\mathrm{CaCO}_{3}$ in Ramhormoz area using geostatistical methods and the imagery of TM sensor as a secondary variable. He showed the relative advantage of geostatistical methods for estimation of soil spatial data. McBratney et al. (2003) provided the comprehensive maps for physical, chemical and biological soil properties by means of geostatistics, GIS and remote sensing techniques for a large area in Australia. Meul and van Meirvenne (2003) used ordinary kriging, comprehensive kriging, simple kriging and cokriging methods for estimation of silt content in Belgium. They also considered digital elevation model (DEM) as a secondary variable and the results showed that the comprehensive kriging method had the lowest estimating error. Ersahin (2003) used kriging and cokriging methods and soil bulk density as an 
auxiliary variable for investigation of the spatial variations of infiltration rate in north west of Turkey. The findings revealed that the cokriging method is a suitable technique for estimation of infiltration rate. Sokoti et al. (2007) used different geostatistical methods in order to predict the soil salinity distribution in Urmia plain, Iran. They found that kriging method with the gaussian model has higher accuracy for estimating of salinity levels in areas without any information. Robinson and Metternicht (2006) used three different techniques including cokriging, IDW and spline for prediction of the levels of the soil salinity, acidity and organic matter. They recognized the spline and cokriging methods are the best approach for estimation of the soil salinity values and organic matter content. Hence, the present study was carried out to evaluate the accuracy of different spatial interpolation methods including kriging, cokriging and IDW methods for prediction of spatial distribution of salinity (EC) and sodium adsorption ratio (SAR) in soils of Ziaran region in Qazvin province, Iran.

\section{MATERIAL AND METHODS}

\section{Site description}

The study was carried out in Ziaran region, Qazvin province in Iran. The land investigated in the research is located between latitudes of $35^{\circ} 51^{\prime}$ and $36^{\circ} 4^{\prime} \mathrm{N}$ and between longitudes of $50^{\circ} 24^{\prime}$ and $50^{\circ} 41^{\prime} \mathrm{E}$. The average, minimum and maximum elevation of Ziaran region are 1204, 1139 and 1269 meters above the sea level, respectively. The soil moisture and temperature regimes of the region by means of Newhall software are Weak Aridic and Thermic, respectively. The soils were classified according to USDA classification system (Soil Survey Staff 2010) as belonging to the Entisols and Aridisols orders. Mean annual precipitation and mean annual air temperature are $230 \mathrm{~mm}$ and $14.6{ }^{\circ} \mathrm{C}$, respectively.

\section{Data collection and soil sample analysis}

The tracking of the soil profiles was done using a Garmin eTrex-H model global positioning system (GPS) receiver. For geostatistical analyzing, sampling was done with stratified random method and soil samples from 0 to $15 \mathrm{~cm}$ depth were collected from sixty soil profiles located in Ziaran region (Fig. 1). After transportation of disturbed soil samples to laboratory, the samples were air-dried at room temperature and then, squashed. The dry samples were ground to pass through a 2 $\mathrm{mm}$ sieve. Electrical Conductivity (EC) in saturation extract, sodium adsorption ratio (SAR), dissolved $\mathrm{Ca}^{2+}, \mathrm{Mg}^{2+}$ and $\mathrm{Na}^{+}$were measured according to methods of soil analysis presented by Sparks et al. (1996). For creation of the attribute table, the soil parameters which included the coordinates specifying the latitudes and longitudes of all the sampling point locations and the soil properties were entered as a table in Excel software and saved in a dBASE IV (DBF 4) format. For evaluating and estimating of spatial variability of EC and SAR, $\mathrm{GS}^{+} 5.1$ software was used.

\section{Spatial prediction methods}

The presence of a spatial structure where observations close to each other are more alike than those that are far apart (spatial 


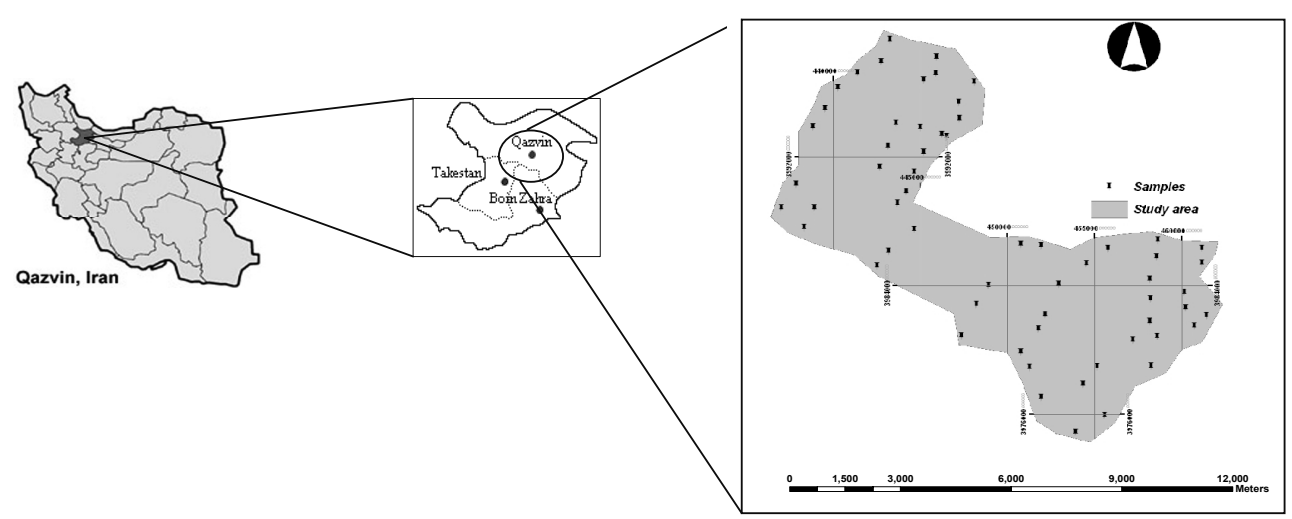

FIGURE 1. Locations of the study area and soil sampling

autocorrelation) is a prerequisite to the application of geostatistics (Goovaerts 1999; Robinson and Metternicht 2006). The experimental variogram measures the average degree of dissimilarity between unsampled values and a nearby data value (Deutsch and Journel 1998) and thus can depict autocorrelation at various distances. The value of the experimental variogram for a separation distance of $h$ (referred to as the lag) is half the average squared difference between the value at $z\left(x_{i}\right)$ and the value at $z\left(x_{i}+h\right)$ (Lark 2000; Robinson and Metternicht 2006):

$$
\gamma(h)=\frac{1}{2 N(h)} \sum_{i=1}^{N(h)}\left[z\left(x_{i}+h\right) z\left(x_{i}\right)\right]^{2}
$$

where:

$N(h)$ is the number of data pairs within a given class of distance and direction. If the values at $z\left(x_{i}\right)$ and $z\left(x_{i}+h\right)$ are auto correlated the result of Eq. (1) will be small, relative to an uncorrelated pair of points. From analysis of the experimental variogram, a suitable model is then fitted, usually by weighted least squares, and the parameters (e.g. range, nugget and sill) are then used in the kriging procedure.

The "co-regionalization" (expressed as correlation) between two variables can be exploited to advantage for estimation purposes by the cokriging technique. In this sense, the advantages of cokriging are realized through reduction in costs or sampling effort. The cross semi-variogram is used to quantify cross spatial auto-covariance between the original variable and the covariate (Webster and Oliver 2001). The cross semi-variance is computed through the Eq. (2):

$\gamma_{u v} h=1 / 2 \mathrm{~N}(h) \sum\left[Z_{u}(x)-Z_{u}(x+h)\right]\left[Z_{v}(x)-Z_{v}(x+h)\right]$

where:

$\gamma_{u v} h$ is cross semi-variance between $u$ and $v$ variables, $Z_{u}(x)$ is primary variable and $Z_{v}(x)$ is secondary variable. In cokriging method, the sum of $\mathrm{Ca}^{2+}+$ $+\mathrm{Mg}^{2+}$ and $\mathrm{Na}^{+}$concentration which were highly correlated with soil salinity and sodium adsorption ratio, respectively, are used as auxiliary parameters.

In interpolation with IDW method, a weight is attributed to the point to be 
measured. The amount of this weight is depended to the distance of the point to another unknown point. These weights are controlled on the bases of power of ten. With increase of power of ten, the effect of the points that are farther diminishes. Lesser power distributes the weights more uniformly between neighboring points. We should keep in mind that in this method the distance between the points count, so the points of equal distance have equal weights (Burrough and McDonnell 1998). In this method the weight factor was calculated with Eq. (3):

$$
\lambda_{i}=\frac{D_{i}^{\alpha}}{\sum_{i=1}^{n} D_{i}^{\alpha}}
$$

where:

$\lambda_{i}$ is the weight of point, $D_{i}$ denotes the distance between point $i$ and the unknown point and $\alpha$ is the power ten of weight.

\section{Comparison of different methods}

Finally, we used the RMSE to evaluate model performance in cross-validation mode. The lowest RMSE indicate the most accurate predictions. The RMSE was derived according to Eq. (4) (Wösten et al. 1999):

$$
R M S E=\sqrt{\frac{1}{n} \sum_{i=1}^{n}\left(z\left(x_{i}\right)-\left(z^{*}\left(x_{i}\right)\right)^{2}\right.}
$$

where:

$z\left(x_{i}\right)$ is observed value at point $x_{i}, z^{*}\left(x_{i}\right)$ is predicted value at point $x_{i}, n$ is number of samples. Conventional statistical anal- yses were conducted using the software package SPSS 13.0 for Windows (SPSS Inc., MatLabR, USA). Geostatistical analyses and mapping were performed by using ArcGIS 9.2 software package (Environmental Systems Research Institute, Redlands, CA).

\section{RESULTS AND DISCUSSION}

A summary of statistical data related to soil properties is presented in Table 1 . The normality of data was tested by Kolmogorov-Smirnov method ( $p$-value $>$ $>0.05)$. Data related to EC $\left(\mathrm{dS} \cdot \mathrm{m}^{-1}\right)$, $\mathrm{SAR}$ and $\mathrm{Na}^{+}$(meq. $\mathrm{L}^{-1}$ ) were normalized using square root method due to the levels of skewness for these soil parameters were between $0.5-1$. Whereas, $\mathrm{Ca}^{2+}+\mathrm{Mg}^{2+}$ (meq. $\mathrm{L}^{-1}$ ) had the level of skewness more than 1 and hence, was normalized using logarithm method.

The first step in using of kriging and cokriging methods is to check the presence of spatial structure among data by variogram analysis. Geostatistical methods were developing to create mathematical models of spatial correlation structures with a variogram as the quantitative measure of spatial correlation. The variogram commonly used in geostatistics and the interpolation techniques, known as kriging, provides the "best", unbiased, linear estimate of a regionalized variable in an unsampled locations, where "best" is defined in a least-squares sense. The kriging estimation variances are independent of the value being estimated and are related only to the spatial arrangement of the sample data and to the model variogram (Webster and Oliver 2001). Semi-variograms related to 
TABLE 1. Results of statistical analysis on studied parameters

\begin{tabular}{|l|c|c|c|c|c|c|c|}
\hline Soil Parameter & Min & Max & Mean & Std & Kurtosis & Skewness & CV $(\%)$ \\
\hline EC $\left(\mathrm{dS} \cdot \mathrm{m}^{-1}\right)$ & 0.39 & 4.17 & 1.72 & 0.97 & -0.21 & 0.77 & 56.40 \\
\hline $\mathrm{EC}\left(\mathrm{dS} \cdot \mathrm{m}^{-1}\right)^{\dagger}$ & 0.62 & 2.04 & 1.26 & 0.36 & -0.76 & 0.30 & 28.50 \\
\hline $\mathrm{SAR}$ & 0.25 & 8.74 & 3.02 & 2.44 & -0.20 & 0.92 & 80.07 \\
\hline $\mathrm{SAR}^{\dagger}$ & 0.50 & 2.96 & 1.59 & 0.70 & -0.91 & 0.35 & 44.02 \\
\hline $\mathrm{Ca}^{2+}+\mathrm{Mg}^{2+}\left(\mathrm{meq} \cdot \mathrm{L}^{-1}\right)$ & 2.90 & 38.70 & 11.57 & 8.12 & 3.12 & 1.90 & 70.18 \\
\hline $\mathrm{Ca}^{2+}+\mathrm{Mg}^{2+}\left(\mathrm{meq} \cdot \mathrm{L}^{-1}\right)^{\dagger}$ & 1.06 & 3.66 & 2.26 & 0.58 & 0.18 & 0.44 & 25.66 \\
\hline $\mathrm{Na}^{+}\left(\mathrm{meq} \cdot \mathrm{L}^{-1}\right)$ & 0.59 & 26.44 & 8.03 & 6.54 & -0.29 & 0.83 & 81.44 \\
\hline $\mathrm{Na}^{+}\left(\mathrm{meq} \cdot \mathrm{L}^{-1}\right)^{\dagger}$ & 0.77 & 5.14 & 2.59 & 1.16 & -1.06 & 0.31 & 44.78 \\
\hline
\end{tabular}

${ }^{\mathrm{a}} \mathrm{CV}=$ coefficent of variation, $\dagger$ using square root to normalized data, $\uparrow$ using logarithm to normalized data

kriging method are presented in Figure 2. The best model for fitting on experimental variogram was selected based on less RSS (residual sums of squares) value (Table 2). Therefore, we recognized the spherical model to be suitable for estimation of EC. Also exponential model was the best for evaluation of the SAR. The variograms of studied soil parameters are shown in Table 3.

The ratio of nugget variance to sill expressed in percentages $\left(\mathrm{C}_{0} / \mathrm{C}+\mathrm{C}_{0}\right)$ can be regarded as a criterion for classifying the spatial dependence of the soil parameters. If this ratio is less than $25 \%$, then the variable has strong spatial dependence (Shi et al. 2005).

As shown in Table 3, EC and SAR have strong spatial structure. The range effect for soil EC and SAR were close to each other $(12-13 \mathrm{~km})$. The range effect for soil EC is approximately 13.07 $\mathrm{km}$ and this parameter which is related to SAR is about $12.33 \mathrm{~km}$ as well. First step for cokriging is computing of cross-variogram. The cross-variogram can be modeled in the same way as that of variograms, and the same restricted set of functions is available. Typically the aim is to estimate just one variable, plus those of one or more other variable, which we regard as auxiliary variable. Cokriging approach reduces the estimations variance which is the advantage of this technique. But, this reduction strongly depends on the number of sampling. Moreover, in cokriging method, after creating a correlation matrix, a parameter which had the highest correlation coefficient with primary variable was selected as an auxiliary variable (Table 4). Hence, the sum of $\mathrm{Ca}^{2+}+\mathrm{Mg}^{2+}$ and $\mathrm{Na}^{+}$ concentration which were highly correlated with soil salinity and sodium adsorption ratio, respectively, are used as auxiliary variables to develop the cross-variogram.

After variogram modeling, three different techniques including kriging, cokriging and IDW methods were used for prediction of spatial distribution of the soil properties and the RMSE was used for comparison of the results. Results showed that kriging and cokriging methods were expected to be superior to IDW method for estimating of soil properties (Table 5). Furthermore, cokriging predictor was the most suitable method 
$E C(d S / m)$
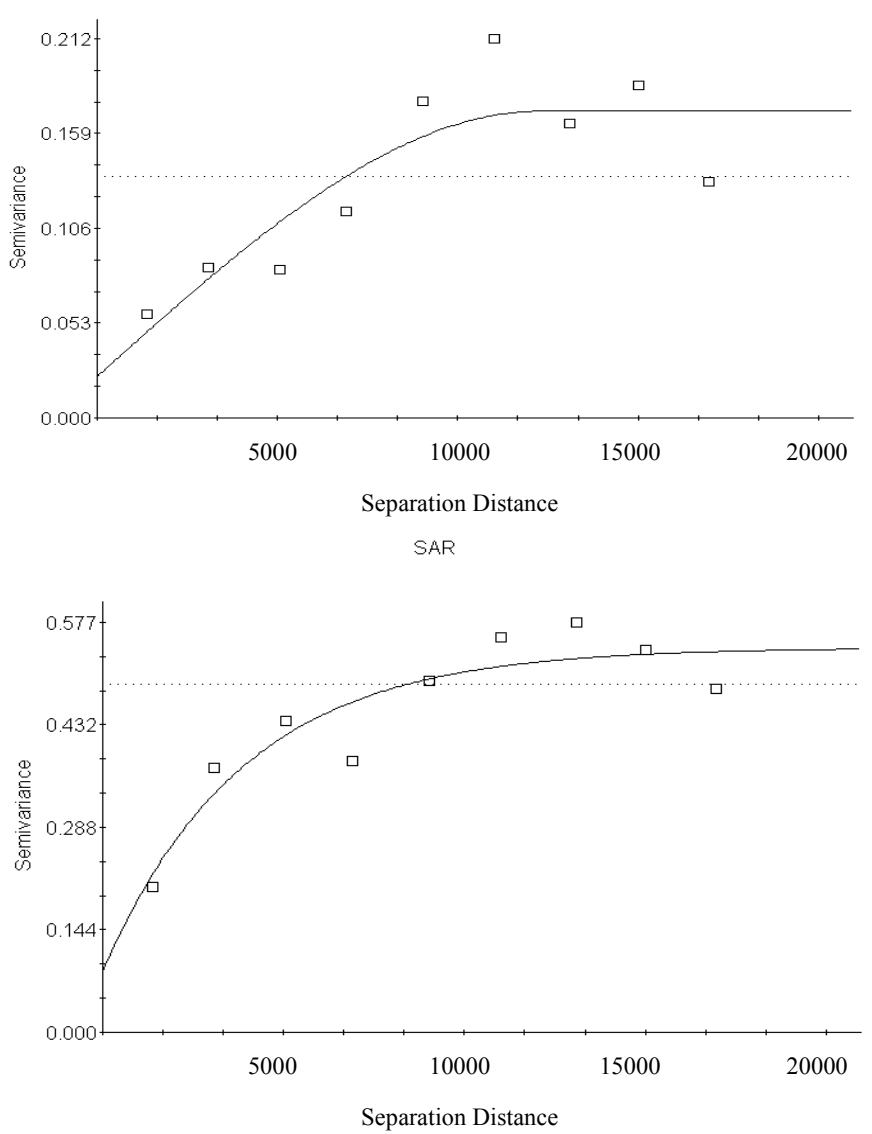

FIGURE 2. Omni-directional semi-variogram related to $\mathrm{EC}\left(\mathrm{dS} \cdot \mathrm{m}^{-1}\right)$ and SAR using kriging method

TABLE 2. Selection of the most suitable model for evaluation of experimental variogram according to RSS value

\begin{tabular}{|l|c|c|c|}
\hline \multirow{2}{*}{ Soil Parameter } & \multicolumn{3}{|c|}{ Model } \\
\cline { 2 - 4 } & Spherical & Exponential & Gaussian \\
\hline EC $\left(\mathrm{dS} \cdot \mathrm{m}^{-1}\right)$ & 0.00525 & 0.00691 & 0.00537 \\
\hline SAR & 0.0173 & 0.0162 & 0.0204 \\
\hline
\end{tabular}

TABLE 3. Best-fitted variogram models of soil properties and their parameters

\begin{tabular}{|l|c|c|c|c|c|}
\hline Soil property & Model & $\begin{array}{c}\text { Nugget } \\
\left(\mathrm{C}_{0}\right)\end{array}$ & $\begin{array}{c}\text { Sill } \\
\left(\mathrm{C}+\mathrm{C}_{0}\right)\end{array}$ & $\begin{array}{c}\text { Range effect } \\
(\mathrm{km})\end{array}$ & $\begin{array}{c}\mathrm{C}_{0} / \mathrm{C}+\mathrm{C}_{0} \\
(\%)\end{array}$ \\
\hline EC $\left(\mathrm{dS} \cdot \mathrm{m}^{-1}\right)$ & Spherical & 0.023 & 0.171 & 13.07 & 13.5 \\
\hline SAR & Exponential & 0.085 & 0.541 & 12.33 & 15.7 \\
\hline
\end{tabular}


TABLE 4. Simple linear correlation coefficients (r) among soil properties

\begin{tabular}{|l|c|c|c|c|}
\hline & $\mathrm{EC}\left(\mathrm{dS} \cdot \mathrm{m}^{-1}\right)$ & $\mathrm{Ca}^{2+}+\mathrm{Mg}^{2+}\left(\mathrm{meq} \cdot \mathrm{L}^{-1}\right)$ & $\mathrm{SAR}$ & $\mathrm{Na}^{+}\left(\mathrm{meq} \cdot \mathrm{L}^{-1}\right)$ \\
\hline $\mathrm{EC}\left(\mathrm{dS} \cdot \mathrm{m}^{-1}\right)$ & 1 & & & \\
\hline $\mathrm{Ca}^{2+}+\mathrm{Mg}^{2+}\left(\mathrm{meq} \cdot \mathrm{L}^{-1}\right)$ & $0.873^{* *}$ & 1 & & \\
\hline $\mathrm{SAR}$ & $0.781^{* *}$ & $0.294^{*}$ & 1 & \\
\hline $\mathrm{Na}^{+}\left(\mathrm{meq} \cdot \mathrm{L}^{-1}\right)$ & $0.748^{* *}$ & $0.653^{* *}$ & $0.970^{* *}$ & 1 \\
\hline
\end{tabular}

${ }^{*}$ significant at the 0.05 level; ${ }^{* *}$ significant at the 0.01 level

TABLE 5. Results of the interpolation error for estimation of soil properties

\begin{tabular}{|l|c|c|c|c|c|}
\hline \multirow{2}{*}{ Soil property } & \multirow{2}{*}{ Kriging } & Cokriging & \multicolumn{3}{|c|}{ IDW } \\
\cline { 4 - 6 } & & $\begin{array}{c}\text { Weighting power } \\
=1\end{array}$ & $\begin{array}{c}\text { Weighting power } \\
=2\end{array}$ & $\begin{array}{c}\text { Weighting power } \\
=3\end{array}$ \\
\hline EC $\left(\mathrm{dS} \cdot \mathrm{m}^{-1}\right)$ & 0.961 & 0.952 & 0.993 & 0.972 & 0.968 \\
\hline SAR & 2.604 & 2.560 & 2.671 & 2.654 & 2.622 \\
\hline
\end{tabular}

for estimation of soil salinity by means of auxiliary variable of $\mathrm{Ca}^{+2}+\mathrm{Mg}^{+2}$ and based on RMSE criterion. Moreover, cokriging method had the most accuracy for prediction of the SAR by means of the auxiliary variable of $\mathrm{Na}^{+}$and based on RMSE criterion. These results are similar to the findings of Meul and van Meirvenne (2003), Shi et al. (2005), Sokoti et al. (2007) and Ayoubi et al. (2007). They recognized that the cokriging method had the most superiority to other methods to predict soil properties as well. Kachanoski et al. (1988) stated that $\mathrm{EC}$ was affected by volumetric water content, and EC increased with increasing water content when clay content was low. Wei et al. (2006) evaluated the soil organic matter distribution in northeast of China and found that the kriging method could predict organic matter distribution with a higher accuracy. Shao et al. (2006) by using of geostatistics techniques and kriging method determined the spatial distribution of the soil nutrients in Hebei province, China. Shi et al. (2005) provided the salinity distribution maps in a coastal saline area in China using geostatistics methods. They reported that for prediction of SAR and EC, the cokriging method was the most suitable one. Similarly, Hosseini et al. (1994) found that the cokriging method had the most accuracy for estimation of SAR level. Finally, the maps of spatial distribution of soil EC and SAR were prepared using cokriging and IDW (weighting power $=2$ ) methods in GIS environment (Figs. 3 and 4).

\section{CONCLUSIONS}

Soil properties are continuous variables and values at any location can vary according to direction and distance of separation from neighboring samples. Salinity and alkalinity exhibit spatial dependence within some localized region. The classical statistics is insufficient for interpolation of spatial dependent variables, because it supposes random variation and does not takes into consideration of spatial correlation, distance of sampling and location of samples. In this study, differ- 

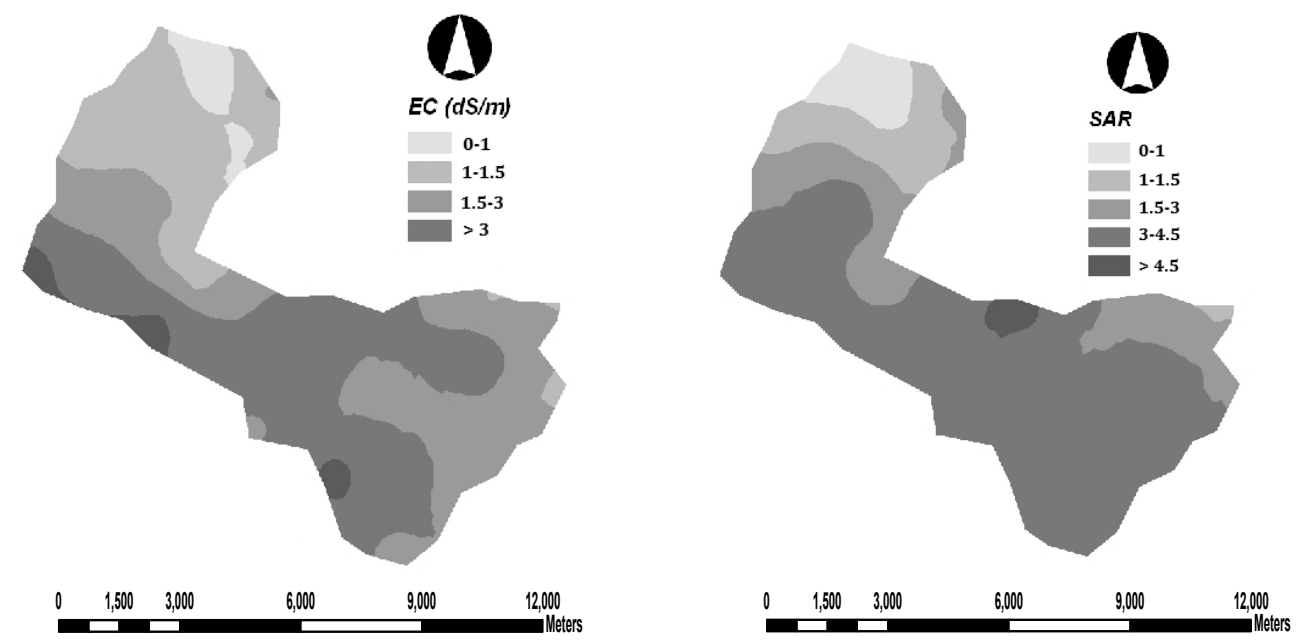

FIGURE 3. Maps of spatial distribution of EC $\left(\mathrm{dS} \cdot \mathrm{m}^{-1}\right)$ and SAR using cokriging method
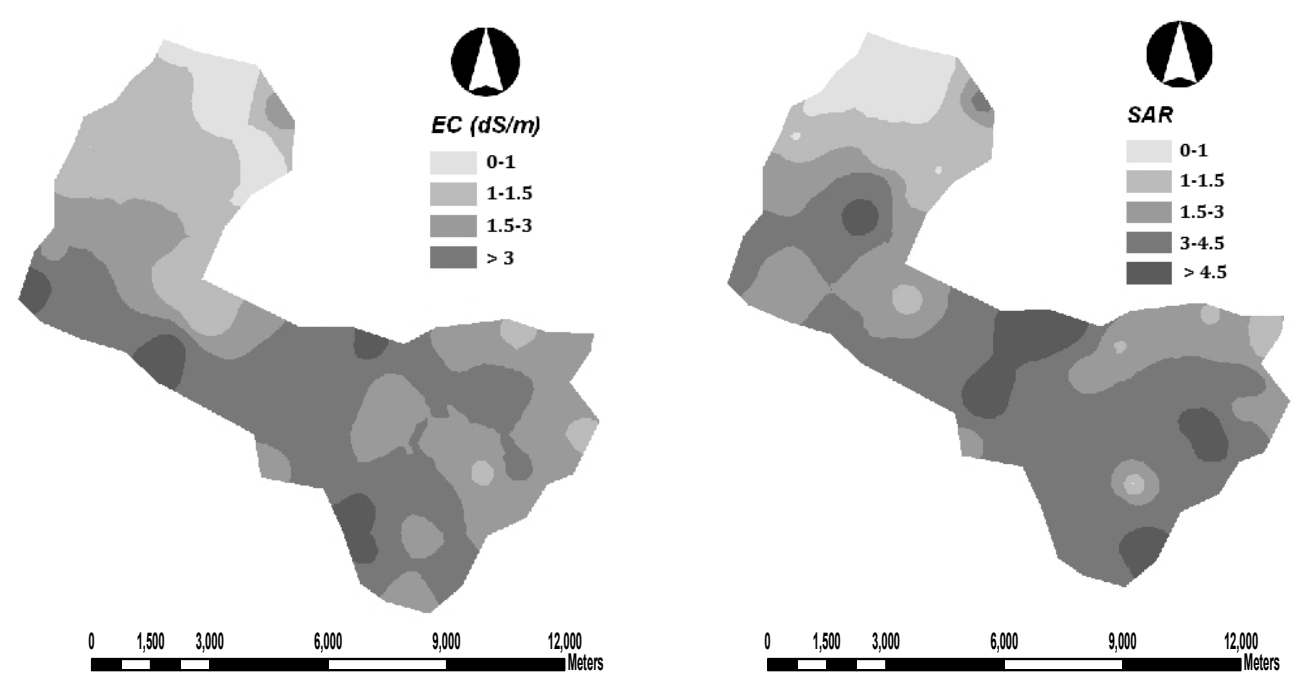

FIGURE 4. Maps of spatial distribution of EC $\left(\mathrm{dS} \cdot \mathrm{m}^{-1}\right)$ and SAR using IDW method (weighting power $=2$ )

ent spatial interpolation methods including kriging, cokriging and IDW methods were compared for prediction of spatial distribution of salinity (EC) and sodium adsorption ratio (SAR) in soils of Ziaran region in Qazvin province, Iran. The results showed that kriging and cokriging methods were better than IDW method for prediction of EC and SAR. In addition, the soil SAR and $\mathrm{Na}^{+}$levels in the study area had high variations (Table 1). The most level of SAR observed in the study area having low elevation (Figs. 3 and 4). The main reason of soil salinity and alkalinity in this area was probably due to the great content of clay particles 
in the soil surface and consequently gathering of specific salts in the surface sections of the topsoil. On the other hand, agricultural activities without consideration to cultivation potential of this area and irregular extraction of groundwater with exceeding use of groundwater can enhance these processes. With regarding to spatial distribution maps of soil properties it seems that in the north west of study area the soil texture is coarser than other sections. So these sections had higher infiltration rate compared with the other areas. Therefore, these areas are suitable for infiltration of water into the soil for nutrition of groundwater tables. Furthermore, in the south of study area the soil clay content was very high and the poor drainage condition of this section was because of these high amounts of clay. The land should be used for agriculture production with the rotation of irrigated plants and non-irrigated plants. However, the level of groundwater table should be under monitored continuously to avoid high levels of EC and SAR.

\section{Acknowledgment}

This study was carried out at the Laboratory of Remote Sensing and GIS, Department of Soil Science Engineering, University of Tehran, Karaj, Iran. The authors would like to express their gratitude to the editor-in-chief, Dr Józef Mosiej, Dr Jarosław Chormański (Department of Hydraulic Engineering and Environmental Reclamation, Warsaw Agricultural University, Poland) and anonymous reviewers for their valuable comments and suggestions.

\section{REFERENCES}

AYERS R.S., WESTCOT D.W. 1989: Water Quality for Agriculture. FAO Irrigation and Drainage. Paper 29, 1-174, Rome.

AYOUBI Sh., MOHAMMAD ZAMANI S., KHORMALI F. 2007: Prediction total N by organic matter content using some geostatistic approaches in part of farm land of Sorkhankalateh, Golestan Province. J. Agric. Sci. Natur. Resour. 14 (4), 65-75.

BOHN H.L., McNEAL B.L., o'CONNOR G.A. 1985: Soil chemistry. Wiley, New York.

BOIVIN P., FAVRE F., HAMMECKER C., MAEGHT J.L., DELARIVIERE J., POUSSIN J.C., WOPEREIS M.C.S. 2002: Processes driving soil solution chemistry in a flooded rice-cropped vertisol: analysis of long-time monitoring data. Geoderma 110, 87-107.

BOKEN V.K., HOOGENBOOM G., HOOK J.E., THOMAS D.L., GUERRA L.C., HARRISON K.A. 2004: Agricultural water use estimation using geospatial modeling and a geographic information system. Agric. Water Manage. 67, 85-199.

BURROUGH P.A., McDONNELL R.A. 1998: Creating continuous surfaces from point data. In: Burrough P.A., Goodchild M.F., McDonnell R.A., Switzer P., Worboys M. (Eds). Principles of Geographic Information Systems. Oxford University Press, Oxford.

CEUPPENS J., WOPEREIS M.C.S., MIEZAN K.M. 1997: Soil salinization processes in rice irrigation schemes in the Senegal River delta. Soil Sci. Soc. Am. J. 61 (4), 1122-1130.

DEUTSCH C.V., JOURNEL A.G. 1998: GSLIB: Geostatistical Software Library and User's Guide. Oxford University Press, Oxford.

DOOLITTLE J.A., SUDDUTH K.A., KITCHEN N.R., INDORANTE S.J. 1994: Estimating depth to claypans using electromagnetic induction methods. Journal of Soil Water Conservation 49, 572-575. 
EMERY X., ORTIZ J.M. 2007: Weighted sample variograms as a tool to better assess the spatial variability of soil properties. Geoderma 140, 81-89.

ERSAHIN S. 2003: Comparing Ordinary Kriging and Cokriging to Estimate Infiltration Rate. Soil Science 67, 1848-1855.

FERREYRA R.A., APEZTEGUIA H.P., SERENO R., JONES J.W. 2002: Reduction of soil water spatial sampling density using scaled semivariograms and simulated annealing. Geoderma 110, 265-289.

GOOVAERTS P. 1999: Geostatistics in soil science: state-of-the-art and perspectives. Geoderma 89, 1-45.

$\mathrm{GS}^{+}$5.1. 2001: Gamma design software. MI.

HOSSEINI E., GALLICHAND E., MARCOTTE D. 1994: Theoretical and experimental performance of spatial interpolation methods for soil salinity analysis. Transactions of the ASAE 37 (6), 1799-1807.

KACHANOSKI R.G., GREGORICH E.G., van WESENBECK I.J. 1988: Estimating spatial variations of soil water content using non-containing electromagnetic inductive methods. Canadian Journal of Soil Science 68, 715-722.

KILIC K., KILIC S. 2007: Spatial variability of salinity and alkalinity of a field having salination risk in semi-arid climate in northern Turkey. Environ. Monitor Assess. 127, 55-65.

LARK R.M. 2000: Estimating variograms of soil properties by the method of moments and maximum likelihood. Eur. J. Soil Sci. 51, 717-728.

LI Y., SHI Z., WU C.F., LI H.X., LI F. 2007: Improved prediction and reduction of sampling density for soil salinity by different geostatistical methods. Agricultural Sciences in China 6, 832-841.

MANKIN K.R., EWING K.L., SCHROCK M.D., KLUITENBERG G.J. 1997: Field measurement and mapping of soil salinity in saline seeps. In: Proceeding for ASAE International Meeting, 10-14 August, No 973145, Minneapolis, MN.
McBRATNEY A.B., MENDONCA M.L., MINANSY B. 2003: On digital soil mapping. Geoderma 117, 3-52.

MEUL M., van MEIRVENNE M. 2003: Kriging soil texture under different types of nonstationarity. Geoderma 112, 217-233.

MOHAMMADI J. 2000: Evaluation and mapping of soil salinity hazard in Ramhormoz area (Khuzestan) using disjunctive Kriging. J. Agricultural Research 25 (6), 45-57.

POSTEL R. 1989: Water of agriculture: Facing the limits, world-watch paper. Washington D.C., Worldwatch Ins.

POZDNYAKOVA L., ZHANG R. 1999: Geostatistical Analyses of Soil Salinity in a Large Field. Precision Agriculture 1, 153-165.

RHOADES J.D., KANDIOH A.P., MASHALI A.M. 1992: The Use of Saline Waters for Crop Production. FAO Irrigation and Drainage. Paper 48. Food and Agricultural Organization of The United Nations, Rome.

ROBINSON T.P., METTERNICHT G.M. 2006: Testing the performance of spatial interpolation techniques for mapping soil properties. Computer and Electronics in Agriculture 50, 97-108.

SHAO W.H., JI Y.J., LI P.Y., YOU L.B. 2006: Spatial Variability of Soil Nutrients and Influencing Factors in a Vegetable Production Area of Hebei Province in China. Nutr. Cycl. Agroecosyst. 75, 201-212.

SHI Z., LI Y., MAKESCHINE F., WANG R.C. 2005: Assessment of temporal and spatial variability of soil salinity in a coastal saline field. Environ. Geo. 48, 171-178.

SOIL SURVEY STAFF. 2010: Keys to Soil Taxonomy, $11^{\text {th }}$ Ed., U.S. Department of Agriculture-Natural Resources Conservation Service, Washington, D.C.

SOKOTI S., MAHDIAN M., MAHMOODI Sh., GHAHRAMANI A. 2007: Comparison the applicability of some geostatistical methods to predict soil salinity, a case study of Urmia plain. J. Pajuhesh \& Sazandegi 74 (1), 90-98. 
SPARKS D.L., PAGE A.L., HELMKE P.A., LEOPPERT R.H., SOLTANPOUR P.N., TABATABAI M.A., JOHNSTON G.T., SUMMER M.E. 1996: Methods of soil analysis. Soil Science Society of America, Madison, WI.

SUDDUTH K.A., KITCHEN N.R., DRUMMOND S.T. 1999: Soil conductivity sensing on claypan soils: Comparison of electromagnetic induction and direct methods. In: Robert P.C., Rust R.H., Larson W.E. (Eds). Proceedings of the $4^{\text {th }}$ Int. Conference on Precision Agriculture, St. Paul, MN, July 19-22. Madison, WI, ASA-CSSA-SSSA, 979-990.

WEBSTER R., OLIVER M.A. 2001: Geostatistis for Environmental Scientists. John Wiley and Sons, Brisbane.

WEI J.B., XIAO D.N., ZHANG X.Y., LI X.Z., LI X.Y. 2006: Spatial Variability of Soil Organic Carbon in Relation to Environmental Factors of a Typical Small Watershed in the Black Soil Region, Northeast China. Environ. Monitor Assess. 121, 597-613.
WÖSTEN J.H.M., LILLY A., NEMES A., LEBAS C. 1999: Development and use of a database of hydraulic properties of European soils. Geoderma 90, 169-185.

Streszczenie: Mapowanie przestrzennej zmienności zasolenia na obszarach o klimacie pótsuchym. Artykuł przedstawia zastosowanie metod geoinformacyjnych do określania przestrzennej zmienności zasolenia zasadowości gleb wykształconych w klimacie półsuchym. Omówiono zastosowanie popularnych technik interpolacyjnych - metody ważonych odwrotnych odległości (Inverse Distance Weighted - IDW) oraz metod geostatystycznych krigingu i kokrigingu. W pracy przedstawiono analizę błędów map wynikowych wykonanych różnymi metodami interpolacyjnymi. Metody geostatystyczne - kriging i kokriging - wykazały większą dokładność w porównaniu do metody IDW.

Slowa kluczowe: EC, SAR, kriging, kokriging IDW, walidacja krzyżowa.

MS. received November 2011 